\title{
PENGUKURAN KINERJA MARKETING MIX DAN PERUMUSAN SRATEGI \\ PEMASARAN UKM BATIK PAMEKASAN \\ (Studi Kasus: UKM Batik Kec. Proppo Kab. Pamekasan)
}

\author{
Kukuh Winarso \\ Imam Al-Farisyi \\ Teknik Industri, Universitas Trunojoyo Madura \\ JL. Raya Telang PO.BOX II Kamal Madura \\ Email: Kukuhutm@gmail.com
}

\begin{abstract}
This research is to find out the marketing on marketing mix and formulating marketing strategies for development of the UKMBatik Pamekasan to be able to compete with other products. The analysis used in this research are importance performance analysis used to measure the marketing mixed on consumer perceptions, PGCV index used to determine the priority scale of marketing mixed and SWOT analysis used to formulating marketing strategies UKMBatik Pamekasan.This research result indicates that the variables product in consumer expectations that the quality of the product batik, a coloring material and subtle product batik.In variable price in the hope that the consumer products already satisfy customers. In variable promotion, consumers were unsatiable for UKM based on variables place it was amazed at the ease of getting people in product markets. Based on the analysis SWOT acquired marketing strategy on UKMBatik Pamekasan namely by increasing the quality of the people to gain market share of broader at home and globally, the government is helping UKM batik to improve product promotion out the land to use the market to provide a bargain price based on the economy condition and to improve relations with the public servants/governance institutions in order to keep consumer products batik Pamekasan.
\end{abstract}

Keywords: Marketing mix, Importance Performance Analysis, PGCV index, SWOT analysis

\section{PENDAHULUAH}

Batik merupakan suatu produk yang telah diwariskan oleh nenek moyang bangsa sabagai suatu ciri khas dan budaya yang perlu dilestarikan. Batik merupakan kekayaan budaya asli Indonesia yang harus kita jaga supaya tidak diakui oleh negara lain, sebagaimana telah ditetapkan oleh badan UNESCO pada tanggal 2 Oktober 2009 sebagai warisan budaya milik Indonesia. Menurut Rusnani dan Andini (2014), Madura merupakan salah satu daerah penghasil produk batik di 


\section{Kukuh Winarso \\ Imam Al-Farisyi}

Indonesia. Batik Madura mempunyai ciri khas (keunikan) tersendiri dan tidak kalah bersaing dengan batik-batik di luar daerah Madura. Dalam dunia perindustrian saat ini,perusahaan diharuskan untuk memenuhi kepuasan pelanggan untuk bisa bersaing dengan perusahaan lainnya khususnya pada produk batik. Produk batik merupakan produk tekstil, dimana untuk saat ini, berbagai jenis tekstil beredar di pasar Indonesia dariproduk lokal hingga produk impor. Detik.com (2014) menuturkan bahwa produksi industri jenis tekstil pada kuartal I-2014 turun sebesar 5,88\% dari periode yang sama pada 2013, dibandingkan dengan kuartal IV-2013 pun turun sebesar 6,61\%. Hal tersebut disebabkan oleh serbuan produk tekstil dari negara lain yang harganya lebih murah dan produk yang lebih menarik, dengan begitu minat konsumen akan tinggi pada produk impor tesebut. Hal tersebut bisa menjadi ancaman pada pemasaran produk batik yang merupakan suatu produk warisan dari nenek moyang Indonesia. Menurut penelitian Rusnani dan andini (2014), salahsatucara yang bisa dilakukan untuk tetap bisa bersaing dengan produk lainnya yaitu dengan menggunakan strategi pemasaran misalnya bauran pemasaran. Bauran pemasaran memiliki empat indikator yang harus diperhatikan, yaitu produk, harga, promosi dan distribusi.

Berdasarkan uraian di atas, peneliti ingin menganalis kinerja marketing mix sesuai dengan persepsi konsumen bagi UKM Batik di wilayah Madura khususnya daerah Pamekasan untuk tetap bisa bersaing dengan produk-produk impor paska diberlakukannya ekonomi yang terintegrasi dalam Masyarakat Ekonomi Asean atau yang biasa dikenal dengan pasar bebas. Strategi pemasaran sangatlah berpengaruh terhadap daya beli konsumen, dengan harapan konsumen tetap percaya pada produk dalam negeri khususnya produk batik. Dengan demikian, diharapkan pemasaran UKM batik Madura dapat meningkat sehingga akan meningkatkan daya saing dengan produk-produk tekstil impor.

\section{TINJAUAN PUSTAKA}

\section{Pemasaran}

Pemasaran merupakan suatu konsep yang harus dilaksanakan sebelum perusahaan memiliki produknya. Pemasaran bukan hanya untuk menjual suatu produk ke konsumen, tetapi pemasaran tersebut bertujuan untuk memuaskan kebutuhan konsumen. Kotler dan Armstrong (2003) menjelaskan bahwa pemasaran adalah suatu tugas yang harus dikerjakan oleh manajer perusahaan untuk menilai kebutuhan, mengukur tingkatan dan peluang perusahaan untuk memperoleh keuntungan. Pemasaran berjalan seiring adanya produk yang dimiliki perusahaan yang memiliki tujuan untuk mendapatkan konsumen baru dan mempertahankan konsumen yang telah ada saat ini dengan meningkatkan daya tarik beli konsumen berdasarkan kinerja produk yang dimiliki. Untuk meningkatkan daya tarik beli konsumen, perusahaan harus menciptakan produk yang mampu bersaing (unggul), penetapan harga, mendistribusikan dan mempromosikan produk tersebut dengan baik.

\section{Marketing Mix}




\section{Jurnal Manajemen Teori dan Terapan \\ Tahun 8. No. 2, Agustus 2015}

Menurut Hermawandan Solihin (2012), bauran pemasaran (marketing mix) merupakan suatu alat yang dikembangkan dan digunakan sebagai stategi oleh perusahan khususnya pada manajer pemasaran. Konsep tersebut terdiri dari unsur-unsur program pemasaran yang dipertimbangkan untuk melaksanakan strategi pemasaran.

Seperangkat alat pemasaran merupakan kegiatan pemasaran yang meliputi 4 macam hal, dimana 4 hal tersebut dipadukan menjadi satu kesatuan sehingga akan menjadi satu paket program yang saling berhubungan satu sama lain. Menurut Indriyo (2008), perpaduan dari 4 macam hal tersebut akan menjadi suatu kunci sukseknya kegiatan pemasaran. Perpaduan dari keempat sarana tersebut tidak hanya sekedar penggabungan antara satu dengan yang lain secara terpisahpisah, akan tetapi harus betul-betul menjadi satu dan saling berkesinambungan antara masalah yang satu dengan yang lainnya sehingga akan terbentuk suatu sinergi antara satu masalah dengan masalah yang lain hingga menjadi kuat dan saling membantu apabila terjadi permasalahan. Empat macam hal tersebut dikenal dengan sebutan 4P yaitu produk, harga, promosi dan distribusi.

\section{Importance Performance Analysis}

Menurut Supranto dalam penelitian Anita (2010), Importance Performance Analysis merupakan suatu konsep yang berasal dari service quality atau yang biasa dikenal dengan SERVQUAL. Konsep ini digunakan untuk mengetahui apa yang diinginkan konsumen dengan mengukur apa yang bisa dilakukan oleh perusahaan agar bisa memberikan kualitas yang tinggi.

Menurut Anita (2010), analisis importance performance ini diawali dengan penyebaran kuisioner kepada pelanggan. Kuisioner tersebut memiliki pertanyaan yang setiap itemnya memiliki dua jawaban, jawaban tersebut berupa skala likert. Pertanyaan tersebut berupa pertanyaan apakah hal tersebut penting dilakukan dan bagaimana kinerjanya, baik atau tidak baik.

Dari hasil yang diperoleh dari kuisioner tentang penilaian terhadap tingkat kepentingan dan kinerja, selanjutnya akan dihitung tingkat kesesuaian antar variabel tersebut. Tingkat kesesuaian diperoleh dari hasil perbandingan antara skor kinerja dengan skor kepentingan.Rumus yang digunakan yaitu sebagai berikut:

$$
T k i=\frac{X i}{Y i} \times 100 \%
$$

Dimana:

Tki $=$ Tingkat kesesuaian responden

$\mathrm{Xi}=$ Skor penilaian kinerja perusahaan

$\mathrm{Yi}_{\mathrm{i}}=$ Skor penilaian kepentingan konsumen

Sumbu $Y$ diisi dengan skor tingkat kepentingan, sumbu $X$ diisi dengan skor kinerja. Untuk mengetahui setiap faktor yang mempengaruhi kepuasan pelanggan, maka dari rumus 2.1 disederhanakan menjadi:

$$
\begin{aligned}
\bar{X} & =\frac{\sum X i}{n} \\
\bar{Y} & =\frac{\sum Y i}{n}
\end{aligned}
$$




\section{Kukuh Winarso \\ Imam Al-Farisyi}

\section{Dimana:}

$\bar{X}=$ Skor rata-rata tingkat kinerja

$\bar{Y}=$ Skor rata-rata tingkat kepentingan

$\mathrm{n}=$ Jumlah responden

Setelah unsur-unsur tersebut diperoleh, selanjutnya tingkat unsur-unsur tersebut dianalisa dengan menggunakan diagram kartesius importance performance analysis (Anita,2010). Diagram kartesius merupakan suatu bangunan yang terdiri atas empat bagian yang dibatasi oleh garis potong tegak lurus pada titik $(\bar{X}, \bar{Y})$. Untuk menghitung rata-rata secara keseluruhan digunakan rumus sebagai berikut:

$$
\begin{gathered}
\overline{\bar{X}}=\frac{\sum_{i=1}^{k} \bar{X} i}{n} \\
\overline{\bar{Y}}=\frac{\sum_{i=1}^{k} \bar{Y} i}{n}
\end{gathered}
$$

Dimana:

$\mathrm{K}=$ Banyaknya faktor yang mempengaruhi kepuasan konsumen

Berikut ini merupakan diagram kartersius yang dimaksud penjelasan tersebut.

\begin{tabular}{|c|c|}
\hline $\begin{array}{c}\text { Prioritas Utama } \\
\text { (I) }\end{array}$ & $\begin{array}{c}\text { Pertahankan Prestasi } \\
\text { (II) }\end{array}$ \\
\hline $\begin{array}{c}\text { Prioritas Rendah } \\
\text { (III) }\end{array}$ & $\begin{array}{c}\text { Berlebihan } \\
\text { (IV) }\end{array}$ \\
\hline
\end{tabular}

Gambar 1. Digram kartesius

(Anita: 2010,hal. 27)

Kuadran pertama (I), yaitu kinerja yang memerlukan penanganan sehingga perlu diprioritaskan oleh pihak manajemen.Kuadran kedua (II), yaitu daerah (kinerja) yang perlu dipertahankan oleh perusahaan.Kuadran ketiga (III), yaitu suatu daerah yang terdapat beberapa faktor menurut konsumen tidak terlalu penting. Kuadran keempat (IV), yaitu kuadran yang dianggap sebagai daerah berlebihan.

\section{Potential Gain in Customer Value's Index}

Menurut Anita (2010), potential gain in customer value's merupakan alat yang digunakan untuk melengkapi hasil dari analisis importance dan performance. Alat ini digunakan untuk menentukan prioritas perbaikan yang harus dilakukan oleh perusahaan.PGCV ini memberikan perbandingan hasil dari diagram importance dan performance secara kuantitatif yang lebih rinci. Langkah-langkah untuk menghitung nilai indeks PGCV adalah sebagai berikut:

1. Achive Customer Value (ACV)

Achive Customer Value ini digunakan untuk menunjukkan nilai yang tercapai dari persepsi konsumen. Rumus untuk menghitung $\mathrm{ACV}$ yaitu:

$$
A C V=\bar{X} \times \bar{Y}
$$

2. Ultimately Desire Customer Value (UDCV) 


\section{Jurnal Manajemen Teori dan Terapan \\ Tahun 8. No. 2, Agustus 2015}

Ultimately desire customer value merupakan nilai akhir yang diinginkan konsumen. Rumus perhitungan UDCV yaitu sebagai berikut:

$$
U D C V=\bar{Y} \times \bar{X} \max
$$

Dimana:

Xmax $=$ nilai performance maksimal dengan skala likert $=5$

3. Indeks PGCV

Pada tahap ini, nilai kualitas paling tinggi dari indeks PGCV dijadikan prioritas utama untuk diperbaiki. Nilai kedua dan selanjutnya dijadikan sebagai urutan perbaikan selanjutnya. Dari nilai indeks PGCV kita bisa melihat atribut yang mana yang harus diprioritaskan untuk diperbaiki agar konsumen menjadi puas. Untuk menghitung nilai indeks PGCV digunakan rumus sebagai berikut:

$$
\text { indeks } P G C V=U D C V-A C V
$$

\section{Analisis SWOT}

Menurut Nizak (2014), Analisis SWOT merupakan suatu analisis yang digunakan untuk mengetahui kekuatan (strenght), kelemahan (weakness), peluang (Opportunity) dan ancaman (threat) yang menentukan kinerja suatu perusahaan. Selain itu, Fredi dalam Nizak (2014), juga menjelaskan bahwa analisis SWOT merupakan suatu analisis yang digunakan untuk mengidentifikasi berbagai faktor secara sistematis untuk merumuskan strategi perusahaan. Analisis tersebut dijelaskan secara kualitatif sehingga bisa memaksimalkan kekuatan dan pelvang, serta meminimalkan kelemahan dan ancaman yang ada pada perusahaan. Perencanaan strategi tersebut harus menganalisa faktor kekuatan, kelemahan, peluang dan ancaman pada kondisi saat ini.

Secara garis besar, analisis SWOT digunakan untuk membandingkan faktor eksternal dan internal. Menurut Nizak (2014), dalam membandingkan faktor internal dengan faktor eksternal digunakan matrik faktor strategi. Matrik faktor strategi tersebut terbagi menjadi dua, yaitu matrik faktor strategi internal atau IFAS (internal strategic factor analysis summary) dan matrik faktor strategi eksternal atau EFAS (eksternal strategic factor analysis summary).

\section{METODE PENELITIAN}

Berdasarkan jenis penelitiannya, penelitian ini termasuk dalam penelitian survey. Penelitian survey merupakan suatu teknik pengumpulan informasi yang dilakukan dengan mengajukan pertanyaan secara langsung kepada responden. Pertanyaan tersebut berupa wawancara atau dengan cara penyebaran kuisioner kepada responden.Teknik pengambilan data dalam penelitian ini yaitu dengan metode survey. Data diperoleh dari hasil wawancara dan penyebaran kuisioner. Kuisioner disebarkan dengan memilih populasi di Kabupaten Pamekasan dengan berbagai pertimbangan. Populasi dari penelitian ini yaitu konsumen batik Madura dengan sampel ditentukan dari metode penentuan sampel yaitu dengan metode purposive sampling. Purposive sampling merupakan suatu metode penentuan sampel yang dengan sengaja jumlah sampelnya ditentukan 


\section{Kukuh Winarso \\ Imam Al-Farisyi}

oleh peneliti. Jumlah sampel yang digunakan dalam penelitian ini yaitu dengan menggunakan rumus menurutFredy (2011):

$$
\begin{aligned}
n & =\frac{Z^{2}}{4 \mu^{2}}(9) \\
& =\frac{1,96^{2}}{4(0,1)^{2}} \\
=96,04 & \approx 100 \text { sampel }
\end{aligned}
$$

Dimana:

$\mathrm{n}$ : ukuran sampel

$Z$ : Tingkat keyakinan sampel yang dibutuhkan dalam penelitian, pada $a=5 \%$ maka $Z=1,96$

$\mu$ : tingkat kesalahan yang ditolerir (ditentukan 10\%)

Rumus tersebut merupakan teknik samplingkemudahan, dimana rumus tersebut digunakan ketika jumlah populasi tidak diketahui secara pasti. Dari perhitungan di atas dapat diketahui bahwa jumlah sampel yang dibutuhkan dalam penelitian ini yaitu 100 sampel.

Berikut ini merupakan flowchart (diagram alur) pada penelitian ini.

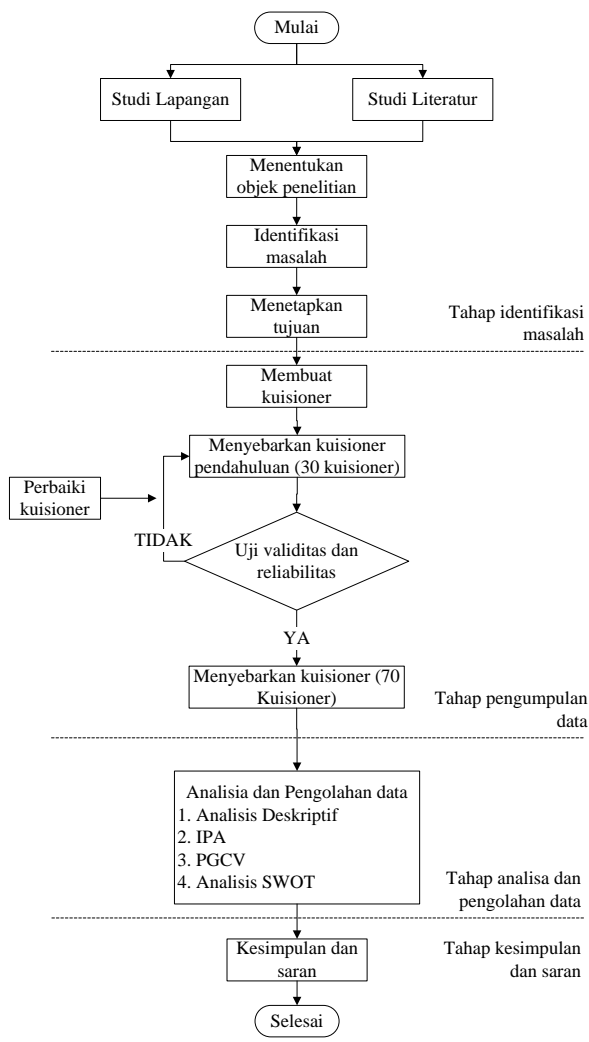

Gambar 2. Flowchartpenelitian

\section{HASIL DAN PEMBAHASAN}

Importance Performance Analysis

Importance Performance Analysis digunakan untuk mengukur kinerja strategi pemasaran berdasarkan marketing mix UKM Batik Pamekasan menurut persepsi konsumen. Analisis IPA terdiri 


\section{Jurnal Manajemen Teori dan Terapan \\ Tahun 8. No. 2, Agustus 2015}

dari dua komponen, yaitu analisis kuadran dan analisis kesenjangan (gap). Berikut ini merupakan hasil dari analisis kuadran masing variabel dari marketing mix.

- Product

Berikut ini merupakan hasil analisis diagram kartesius tingkat kinerja dan tingkat kepentingan pada variabel product.

a. Kuadran I merupakan daerah kuadran yang perlu diprioritaskan untuk dilakukan perbaikan oleh UKM. Indikator-indikator yang termasuk dalam kuadran I ini yaitu adanya merk pada produk batik, kelengkapan informasi pada kemasan dam motif batik bervariasi.

b. Kuadran II merupakan daerah kuadran yang perlu dipertahankan oleh UKM. Indikator-indikator tersebut yaitu kualitas warna pada produk batik, bahan pewarna dan kehalusan produk batik.

c. Kuadran Illmerupakan daerah kuadran yang dikatakan sebagai daerah prioritas rendah. Indikator-indikator yang termasuk dalam kuadran III ini yaitu kualitas kain pada produk batik terjamin.

d. Kuadran IVmerupakan daerah kuadran yang bisa dikatakan sebagai daerah yang berlebihan. Indikator-indikator yang termasuk dalam kuadran IV ini yaitu tersedia berbagai jenis produk batik dan keberagaman warna pada produk batik.

- Price

Berikut ini merupakan hasil analisis diagram kartesius tingkat kinerja dan tingkat kepentingan pada variabel price.

a. Kuadran Imerupakan daerah kuadran yang perlu diprioritaskan untuk dilakukan perbaikan oleh UKM. Pada kuadran I ini tidak ada indikator-indikator yang termasuk kedalam daerah ini.

b. Kuadran IImerupakan daerah kuadran yang perlu dipertahankan oleh UKM. Indikator-indikator tersebut yaitu harga terjangkau dan harga sesuai dengan kualitas bahan.

c. Kuadran Illmerupakan daerah kuadran yang dikatakan sebagai daerah prioritas rendah. Indikator-indikator yang termasuk dalam kuadran III ini yaitu harga sesuai dengan kualitas motif.

d. Kuadran IVmerupakan daerah kuadran yang bisa dikatakan sebagai daerah yang berlebihan. Pada kuadran IV ini tidak ada indikator-indikator yang termasuk kedalam daerah ini.

- Promotion

Berikut ini merupakan hasil analisis diagram kartesius tingkat kinerja dan tingkat kepentingan pada variabel promotion.

a. Kuadran Imerupakan daerah kuadran yang perlu diprioritaskan untuk dilakukan perbaikan oleh UKM. Indikator yang termasuk dalam kuadran I ini yaitu mengetahui informasi produk dari kerabat.

b. Kuadran IImerupakan daerah kuadran yang perlu dipertahankan oleh UKM. Pada kuadran II ini tidak ada indikator-indikator yang termasuk kedalam daerah ini.

c. Kuadran Illmerupakan daerah kuadran yang dikatakan sebagai daerah prioritas rendah. Indikator-indikator yang termasuk dalam kuadran III ini yaitu tersedianya potongan harga dan mengetahui informasi produk dari pameran. 


\section{Kukuh Winarso \\ Imam Al-Farisyi}

d. Kuadran IVmerupakan daerah kuadran yang bisa dikatakan sebagai daerah yang berlebihan. Indikator yang termasuk dalam kuadran IV ini yaitu mengetahui informasi produk melalui sosial media.

- Place

Berikut ini merupakan hasil analisis diagram kartesius tingkat kinerja dan tingkat kepentingan pada variabel place.

a. Kuadran Imerupakan daerah kuadran yang perlu diprioritaskan untuk dilakukan perbaikan oleh UKM. Indikator-indikator yang termasuk dalam kuadran I ini yaitu bisa dibeli di toko-toko misal: butik.

b. Kuadran IImerupakan daerah kuadran yang perlu dipertahankan oleh UKM. Indikator-indikator tersebut yaitu tempat pembelian mudah dijangkau.

c. Kuadran IIImerupakan daerah kuadran yang dikatakan sebagai daerah prioritas rendah. Indikator-indikator yang termasuk dalam kuadran III ini yaitu bisa dibeli di pasar tradisional.

d. Kuadran IVmerupakan daerah kuadran yang bisa dikatakan sebagai daerah yang berlebihan. Indikator-indikator yang termasuk dalam kuadran IV ini yaitu bisa dibeli secara online.

\section{Potential Gain of Customer Value's}

Untuk melengkapi hasil analisa dari Importance Performance, digunakan sebuah metode untuk menentukan prioritas perbaikan yang harus dilakukan oleh UKM Batik. PGCV memberikan jalan bagi diagram Importance Performance untuk dapat dibandingkan dalam bentuk yang lebih teliti dan teperinci. Dalam menghitung nilai indeks PGCV langkah-langkahya yaitu dengan menghitung nilai achive customer value, ultimately desire customer value dan indeks PGCV.

Berikut ini merupakan hasil perhitungan indeks PGCV yang merupakan hasil pengurangan antara nilai UDCV dengan nilai $A C V$ pada variabel product.

Tabel 1. Nilai indeks PGCVvariabel product

\begin{tabular}{|c|l|c|c|c|c|}
\hline No & \multicolumn{1}{|c|}{ Indikator Penilaian } & ACV & UDCV & PGCV & Urutan \\
\hline 1 & Tersedia berbagai jenis produk batik & 11.05 & 17.00 & 5.95 & 9 \\
\hline 2 & Motif batik bervariasi & 10.38 & 17.30 & 6.92 & 8 \\
\hline 3 & Kualitas kain pada produk batik terjamin & 9.95 & 16.00 & 6.05 & 7 \\
\hline 4 & Kualitas warna pada produk batik & 11.08 & 17.20 & 6.12 & 6 \\
\hline 5 & Keberagaman warna pada produk batik & 10.68 & 16.95 & 6.27 & 5 \\
\hline 6 & Bahan pewarna & 11.41 & 17.45 & 6.04 & 2 \\
\hline 7 & Kehalusan produk batik & 11.30 & 17.60 & 6.30 & 4 \\
\hline 8 & Adanya Merk pada produk batik & 10.26 & 17.50 & 7.25 & 1 \\
\hline 9 & Kelengkapan informasi pada kemasan & 10.42 & 17.20 & 6.78 & 3 \\
\hline
\end{tabular}

Pada tabel di atas dapat diketahui bahwa nilai kualitas paling tinggi dari indeks PGCV dijadikan prioritas utama untuk diperbaiki. Nilai kedua dan selanjutnya dijadikan sebagai urutan perbaikan selanjutnya. Dari tabel di atas dapat diketahui bahwa yang menjadi prioritas utama untuk diperbaiki yaitu pada merk produk batik dan seterusnya mengikuti nomor urutan perbaikan masing-masing.

Berikut ini merupakan hasil perhitungan indeks PGCV yang merupakan hasil pengurangan antara nilai UDCV dengan nilai ACV pada variabel price. 
Tabel 2. Nilai indeks PGCVvariabel price

\begin{tabular}{|c|l|c|c|c|c|}
\hline No & \multicolumn{1}{|c|}{ Indikator Penilaian } & ACV & UDCV & PGCV & Urutan \\
\hline 1 & Harga terjangkau & 11.50 & 17.75 & 6.25 & 3 \\
\hline 2 & Harga sesuai dengan kualitas bahan & 10.96 & 17.45 & 6.49 & 2 \\
\hline 3 & Harga sesuai dengan kualitas motif & 10.18 & 16.80 & 6.62 & 1 \\
\hline
\end{tabular}

Pada tabel di atas dapat diketahui bahwa nilai kualitas paling tinggi dari indeks PGCV dijadikan prioritas utama untuk diperbaiki. Nilai kedua dan selanjutnya dijadikan sebagai urutan perbaikan selanjutnya. Dari tabel di atas dapat diketahui bahwa yang menjadi prioritas utama untuk diperbaiki yaitu harga yang sesuai dengan motif pada batik dan seterusnya mengikuti nomor urutan perbaikan masing-masing.

Berikut ini merupakan hasil perhitungan indeks PGCV yang merupakan hasil pengurangan antara nilai UDCV dengan nilai ACV pada variabel promotion.

Tabel 3. Nilai indeks PGCV variabel promotion

\begin{tabular}{|c|l|c|c|c|c|}
\hline No & \multicolumn{1}{|c|}{ Indikator Penilaian } & ACV & UDCV & PGCV & Urutan \\
\hline 1 & Tersedianya potongan harga & 10.17 & 16.45 & 6.28 & 2 \\
\hline 2 & Mengetahui informasi produk melalui sosial & 11.25 & 16.40 & 5.15 & 4 \\
\hline 3 & Mengetahui informasi produk dari kerabat & 10.51 & 16.85 & 6.34 & 1 \\
\hline 4 & Mengetahui informasi produk dari pameran & 10.49 & 16.55 & 6.06 & 3 \\
\hline
\end{tabular}

Pada tabel di atas dapat diketahui bahwa nilai kualitas paling tinggi dari indeks PGCV dijadikan prioritas utama untuk diperbaiki. Nilai kedua dan selanjutnya dijadikan sebagai urutan perbaikan selanjutnya. Dari tabel di atas dapat diketahui bahwa yang menjadi prioritas utama untuk diperbaiki yaitu promosi produk dengan mengetahui produk batik dari kerabat dekat konsumen dan seterusnya mengikuti nomor urutan perbaikan masing-masing.

Berikut ini merupakan hasil perhitungan indeks PGCV yang merupakan hasil pengurangan antara nilai UDCV dengan nilai ACV pada variabel place.

Tabel 4. Nilai indeks PGCVvariabel place

\begin{tabular}{|c|l|c|c|c|c|}
\hline No & \multicolumn{1}{|c|}{ Indikator Penilaian } & ACV & UDCV & PGCV & Urutan \\
\hline 1 & Tempat pembelian mudah dijangkau & 11.66 & 18.00 & 6.34 & 2 \\
\hline 2 & Bisa dibeli di pasar tradisional & 10.14 & 16.25 & 6.11 & 3 \\
\hline 3 & Bisa dibeli di toko-toko Misal: Butik & 11.55 & 18.05 & 6.50 & 1 \\
\hline 4 & Bisa dibeli secara online & 11.32 & 16.65 & 5.33 & 4 \\
\hline
\end{tabular}

Pada tabel di atas dapat diketahui bahwa nilai kualitas paling tinggi dari indeks PGCV dijadikan prioritas utama untuk diperbaiki. Nilai kedua dan selanjutnya dijadikan sebagai urutan perbaikan selanjutnya. Dari tabel di atas dapat diketahui bahwa yang menjadi prioritas utama untuk diperbaiki yaitu adanya produk batik dibutik dan seterusnya mengikuti nomor urutan perbaikan masing-masing.

\section{ANALISIS SWOT}

SWOT merupakan alat analisis untuk melihat kekuatan baik internal maupun ekternal yang dimiliki UKM Batik Pamekasan, sehingga dapat merumuskan strategi perusahaan dalam 


\section{Kukuh Winarso Imam Al-Farisyi}

persaingannya di pasaran.Analisis SWOT ini dilakukan dengan Menganalisis faktor strategi internal atau IFAS (Internal Strategic Factors Analysis Summary) dan faktor strategis eksternal atau EFAS (External Strategic Factors Analysis Summary), membuat matrik ruang (Space Matriks), serta menyusun keputusan strategis.

\section{IFAS (Internal Strategic Factors Analysis Summary)}

Faktor internal terdiri dari dua komponen yaitu kekuatan (strength) dan kelemahan (weakness). Kedua faktor internal tersebut diambil dari atribut IPA, dimana strength (kekuatan) diambil dari atribut IPA yang termasuk dalam Kuadran II sedangkan weakness (kelemahan) diambil dari atribut IPA yang termasuk dalam Kuadran I. Berikut ini merupakan faktor internal yang dimiliki oleh UKM Batik Pamekasan.

Tabel 5.Internal strategic factors analysis summary UKM Batik Pamekasan

\begin{tabular}{|c|c|c|c|}
\hline Faktor Strategis & Bobot & Rating & Skor \\
\hline \multicolumn{4}{|l|}{ Kekuatan } \\
\hline Kualitas warna pada produk batik & 0.14 & 2 & 0.29 \\
\hline Bahan pewarna & 0.16 & 3 & 0.48 \\
\hline Kehalusan produk batik & 0.15 & 4 & 0.61 \\
\hline Harga terjangkau & 0.21 & 4 & 0.83 \\
\hline Harga sesuai dengan kualitas bahan & 0.18 & 4 & 0.7 \\
\hline Tempat pembelian mudah dijangkau & 0.16 & 2 & 0.32 \\
\hline Jumlah & 1 & & 3.23 \\
\hline \multicolumn{4}{|l|}{ Kelemahan } \\
\hline Motif batik kurang bervariasi & 0.15 & 3 & 0.46 \\
\hline tidak adanya merk pada produk batik & 0.14 & 2 & 0.28 \\
\hline Kurangnya kelengkapan informasi pada kemasan & 0.19 & 3 & 0.56 \\
\hline kurangnya informasi produk dari kerabat & 0.24 & 4 & 0.98 \\
\hline Minimnya butik yang menjual batik & 0.28 & 2 & 0.55 \\
\hline Jumlah & 1 & & 2.83 \\
\hline \multicolumn{3}{|l|}{ Total } & 6.06 \\
\hline
\end{tabular}

EFAS (External Strategic Factors Analysis Summary)

Faktoreksternalterdiridariduakomponenyaitupeluang (opportunities) dan ancaman (treatment). Kedua faktor eksternal tersebut diambil dari pendapat responden yaitu tenaga ahli (sentra batik). Pendapat tersebut berupa peluang dan ancaman yang dimiliki oleh UKM Batik Pamekasan. Berikut ini merupakan faktor eksternal yang dimiliki oleh UKM Batik Pamekasan. Tabel 6.External strategic factors analysis summary UKM Batik Pamekasan

\begin{tabular}{|c|c|c|c|}
\hline Faktor Strategis & Bobot & Rating & Skor \\
\hline \multicolumn{4}{|l|}{ Peluang } \\
\hline Kesempatan untuk memasarkan batik terbuka & 0.45 & 4 & 1.8 \\
\hline Persaingan batik di pasar global tidak ada & 0.11 & 3 & 0.33 \\
\hline Dukungan dari pemerintah terbuka lebar & 0.22 & 4 & 0.86 \\
\hline Adanya kewajiban PNS menggunakan batik & 0.22 & 4 & 0.9 \\
\hline Jumlah & 1 & & 3.89 \\
\hline \multicolumn{4}{|l|}{ Ancaman } \\
\hline Harga produk lain yang lebih murah & 0.41 & 3 & 1.23 \\
\hline Perubahan gaya hidup yang lebih memilih produk & 0.26 & 4 & 1.04 \\
\hline Banyaknya produkimpor yang masuk ke pasaran & 0.33 & 3 & 0.98 \\
\hline Jumlah & 1 & & 3.26 \\
\hline \multicolumn{3}{|l|}{ Total } & 7.15 \\
\hline
\end{tabular}

\section{MatrikSPACE}

Matrik space atau bisa disebut dengan matrik ruang merupakan sebuah diagram yang digunakan untuk mengetahui posisi perusahaan. Berdasarkan hasil pembobotan pada IFAS dan 
EFAS maka dapat diperoleh nilai rating faktor internal yaitu 3,23-2,83 $=0,4$. Nilai tersebut dijadikan sebagai sumbu horizontal atau sumbu X. Sedangkan pada nilai faktor eksternal yaitu 3,89-3,26= 0,63 dimana nilai tersebut dijadikan sebagai sumbu vertical atau sumbu Y. Berikut ini merupakan matrik space UKM Batik Pamekasan.

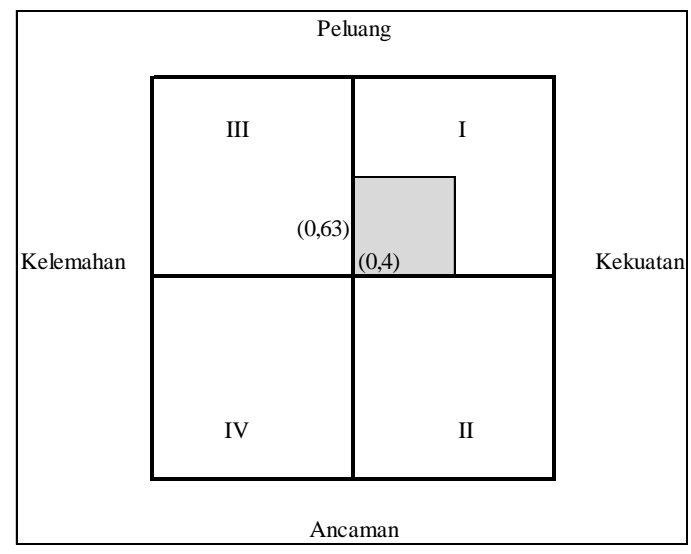

Gambar 3. Posisi pengembangan pemasaran UKM Batik Pamekasan

Berdasarkan matrik space di atas, dapat diketahui bahwa posisi strategi pengembangan pemasaran berada pada kuadran I, dimana pada kuadran tersebut UKM Batik Pamekasan memiliki posisi yang kuat dan berpeluang.

Matrik SWOT

Dengan melihat faktor kekuatan, kelemahan, peluang dan ancaman pada UKM Batik Pamekasan, dapat dirumuskan beberapa strategi pengembangan pemasaran tersebuł yang tercantum pada matrik SWOT di bawah ini. 
Tabel 7. Matrik SWOT perumusan strategi pemasaran UKM Batik Pamekasan

\begin{tabular}{|c|c|c|}
\hline & Strenght (S) & Weakness (W) \\
\hline IFAS & $\begin{array}{l}\text { 1. Kualitas warna pada } \\
\text { produk batik } \\
\text { 2. Bahan pewarna } \\
\text { 3. Kehalusan produk batik } \\
\text { 4. Harga terjangkau } \\
\text { 5. Harga sesuai dengan } \\
\text { kualitas bahan } \\
\text { 6. Tempat pembelian mudah } \\
\text { dijangkau }\end{array}$ & $\begin{array}{l}\text { 1. Motif batik yang masih } \\
\text { kurang bervariasi } \\
\text { 2. Tidak adanya merk pada } \\
\text { produk batik } \\
\text { 3. Tidak ada kelengkapan } \\
\text { informasi pada kemasan } \\
\text { 4. Kurangnya informasi } \\
\text { produk dari kerabat } \\
\text { 5. Ketersedian produk batik } \\
\text { di butik kurang }\end{array}$ \\
\hline Opportunity (O) & Strategi SO & Strategi WO \\
\hline 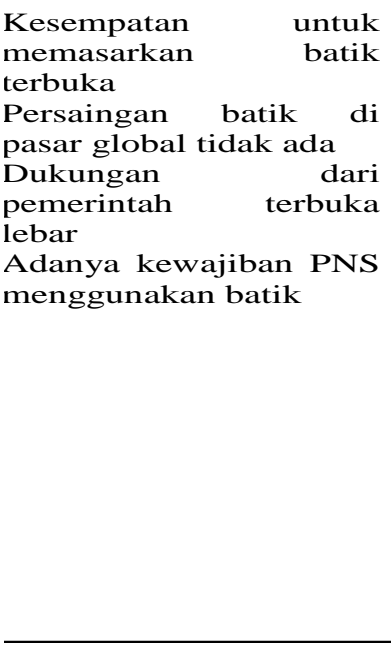 & $\begin{array}{l}\text { 1. Meningkatkan kualitas } \\
\text { produk batik untuk } \\
\text { mendapatkan pangsa pasar } \\
\text { yang lebih luas di dalam } \\
\text { negeri bahkan global. (S 1, } \\
\text { S2, S3, O1, O2) membantu } \\
\text { 2. Pemerintah meningkatkan } \\
\text { UKM batik mening } \\
\text { promosi produk keluar } \\
\text { negeri. (O3) } \\
\text { 3. Memanfaatkan kondisi } \\
\text { pasar dengan memberikan } \\
\text { penawaran harga sesuai } \\
\text { dengan keadaan ekonomi } \\
\text { masyarakat (S4, S5, O1) } \\
\text { 4. Meningkatkan hubungan } \\
\text { dengan pegawai negeri/ } \\
\text { instansi pemerintah agar } \\
\text { menjadi konsumen tetap } \\
\text { produk batik Pamekasan } \\
\text { (S4, O4) }\end{array}$ & $\begin{array}{l}\text { 1. Pemerintah memberikan } \\
\text { pelatihan tentang inovasi } \\
\text { motif yang baru pada } \\
\text { produk batik (W1, O3) } \\
\text { 2. Pemerintah memberikan } \\
\text { arahan tentang } \\
\text { kelengkapan atribut } \\
\text { produk seperti merk dan } \\
\text { kemasan (W2, W3, O3) } \\
\text { 3. Membuka distribusi } \\
\text { pemasaran yang baru } \\
\text { seperti butik-butik } \\
\text { khusus batik (W5, O1, } \\
\text { O2) }\end{array}$ \\
\hline Threats (T) & Strategi ST & Strategi WT \\
\hline $\begin{array}{l}\text { Harga produk lain yang } \\
\text { lebih murah } \\
\text { Perubahan gaya hidup } \\
\text { yang lebih memilih } \\
\text { produk lain } \\
\text { Banyaknya produk } \\
\text { impor yang masuk ke } \\
\text { pasaran }\end{array}$ & $\begin{array}{l}\text { 1. Meningkatkan motif warna } \\
\text { pada produk batik sesuai } \\
\text { dengan tren masa kini ( } 1 \text {, } \\
\mathrm{S} 2, \mathrm{~T} 2, \mathrm{~T} 3) \\
\text { 2. Meningkatkan kualiatas } \\
\text { produk dengan harga } \\
\text { produk tetap terjangkau } \\
(\mathrm{S} 1, \mathrm{~S} 2, \mathrm{~S} 3, \mathrm{~S} 4, \mathrm{~S} 5, \mathrm{~T} 1)\end{array}$ & $\begin{array}{l}\text { 1. Meningkatkan penjualan } \\
\text { produk batik di butik } \\
\text { (W5, T2, T3) } \\
\text { 2. Meningkatkan promosi } \\
\text { dari mulut ke mulut } \\
\text { tentang } \\
\text { produk batik dari pada } \\
\text { produk lain. (W4, T1, } \\
\text { T3) }\end{array}$ \\
\hline
\end{tabular}

Berdasarkan hasil dari diagram matrik space diketahui bahwa posisi UKM Batik Pamekasan berada pada kuadran I, dimana pada kuadran tersebut UKM Batik Pamekasan memiliki posisi yang kuat dan berpeluang. Maka dari itu, strategi yang dipilih pada matrik SWOT di atas yaitu strategi ST. Pada strategi ST terdapat beberapa strategi untuk pengembangan pemasaran pada produk batik Pamekasan, strategi-strategi tersebut yaitu: 


\section{Jurnal Manajemen Teori dan Terapan \\ Tahun 8. No. 2, Agustus 2015}

1. Meningkatkan kualitas produk batik untuk mendapatkan pangsa pasar yang lebih luas di dalam negeri bahkan global

2. Pemerintah membantu UKM batik meningkatkan promosi produk keluar negeri

3. Memanfaatkan kondisi pasar dengan memberikan penawaran harga sesuai dengan keadaan ekonomi masyarakat

4. Meningkatkan hubungan dengan pegawai negeri/instansi pemerintah agar menjadi konsumen tetap produk batik Pamekasan

\section{KESIMPULAN DAN SARAN}

Berdasarkan hasil dan pembahasan pada BAB IV, kesimpulan pada penelitian "Pengukuran Kinerja Marketing Mix dan Perumusan Strategi Pemasaran UKM Batik Pamekasan" ini adalah sebagai berikut:

1. Kinerja pemasaran berdasarkan marketing mix pada UKM Batik pamekasan yaitu:

a. Product

Pada variabel ini kinerja pemasaran yang dapat dinilai belum memuaskan konsumen yaitu belum adanya merk pada produk, tidak adanya kemasan pada produk batik (dalam hal ini kemasan sangat penting untuk menampilkan informasi tentang produk seperti cara perawatan) dan motif batik yang masih kurang bervariasi. Sedangkan konsumen yang telah merasa puas terhadap kinerja produk yaitu kualitas warna pada produk batik, bahan pewarna dan kehalusan produk batik.

b. Price

Pada variabel ini kinerja pemasaran yang ditinjau dari segi harga produk sudah memuaskan konsumen. Hal tersebut dikarenakan harga produk batik Pamekasan terjangkan dan harga tersebut sesuai dengan kualiatas dari produk.

c. Promotion

Pada variabel ini kinerja pemasaran yang ditinjau dari segi promosi produk belum memuaskan konsumen. Hal tersebut dikarenakan konsumen masih rendah dalam hal mengetahui tentang produk tersebut dari orang-orang terdekat mereka. Salah satu jenis promosi yang bisa menarik minat konsumen yaitu dengan mengetahui informasi produk dari orang-orang terdekat.

d. Place

Pada variabel ini kinerja pemasaran berdasarkan tempat memperoleh produk yang dapat dinilai belum memuaskan konsumen yaitu minimnya toko-toko batik jenis butik yang ada di Kabupaten Pamekasan. Sedangkan konsumen yang telah merasa puas terhadap kinerja tempat pemasaran yaitu produk batik bisa didapat dengan mudah seperti di pasar.

2. Perumusan strategi pemasaran UKM Batik Pamekasan untuk tetap bisa bersaing dengan produk-produk tekstil lainnya yaitu dengan melakukan hal-hal sebagai berikut: 


\section{Kukuh Winarso \\ Imam Al-Farisyi}

a. Meningkatkan kualitas produk batik untuk mendapatkan pangsa pasar yang lebih luas di dalam negeri bahkan global

b. Pemerintah membantu UKM batik meningkatkan promosi produk keluar negeri

c. Memanfaatkan kondisi pasar dengan memberikan penawaran harga sesuai dengan keadaan ekonomi masyarakat

d. Meningkatkan hubungan dengan pegawai negeri/instansi pemerintah agar menjadi konsumen tetap produk batik Pamekasan

Saran yang bisa diberikan peneliti untuk meningkatkan pemasaran berdasarkan hasil dari penelitian ini yaitu:

1. UKM Batik Pamekasan disarankan untuk memberikan label atau merk dan kemasan pada produk, meningkatkan hubungan dengan masyarakat agar bisa menarik minat untuk membeli produk batik serta menjual produk di tempat sejenis butik.

2. Untuk penelitian selanjutnya dalam perumusan strategi pemasaran diharapkan menggunakan suatu analisis untuk memprioritaskan strategi strategi mana yang harus dilakukan terlebih dahulu.

\section{DAFTAR PUSTAKA}

Aprianto, B. R dkk. 2015. Analisis Faktor Yang Mempengaruhi Persepsi Pelaku Usaha Batik Di Kota Yogyakarta Dalam Menghadapi Masyarakat Ekonomi Asean (MEA) 2015. University Research Colloquium 2015, 117-126

Atina. 2010. Analisa Kepuasan Pelanggan dan Kualitas Pelayanan dalam Memberikan Pelayanan Kesehatan di Rumah Sakit Menggunakan Metode Importance Analysis dan Potential Gain in Customer Value's. Tugas akhir. Jurusan Teknik Industri, Universitas Islam Indonesia: Yogyakarta Basri, C. 2014. Masyarakat Ekonomi ASEAN Peluang atau Ancaman? Peningkatan daya saing tak bisa ditunda, Kesiapan menjadi kunci utama. Media Keuangan: Transparansi Informasi Kebijakan Fiskal. Vol. IX, No. 80, April 2014

Detik.com. 2014. Produksi Tekstil RI Turun Gara-gara Serbuan Barang Impor. http://m.detik.com/news/transisipresiden/read/2014/05/02/153053/2571620/4/produksi-

tekstil-ri-turun-gara-gara-serbuan-barang-impor. Diakses tanggal 28 Maret 2015.

G, Indriyo. 2008. Manajemen Pemasaran. BPFE-Yogyakarta:Yogyakarta

Gaspersz, V. 2007. Ekonomi Manajerial Pembuatan Keputusan Bisnis. Edisi Revisi dan Perluasan. PT.

Gramedia Pustaka Utama: Jakarta

Hermawan, M dan Solihin, S. 2012. Usulan Strategi Pemasaran Produk Garam (Studi Kasus: Produk Garam Karya Tani). Jurnal Integra, Vol. 2, No. 1, Juni 2012, 77-94

Kotler, P dan Armstrong, G. 2004. Dasar-Dasar Pemasaran.PT. Macanan Jaya Cemerlang:Jakarta Kotler, P dan Keller, K. L. 2008. Manajemen Pemasaran. Erlangga: Jakarta 
Nisak, Z. 2014. Analisis SWOT untuk Menentukan Strategi Kompetitif. Jurnal EKBIS. Fakultas Ekonomi: Universitas Islam Lamongan

Novandari dkk. 2011. Analisis Kinerja Produk Ukm Batik Banyumas Dengan Menggunakan Metode Importance Performance Analysis dan Potential Gain Of Customer Valve's. Jurnal Bisnis dan Ekonomi (JBE), Vol. 18 No.2, September 2011, 104-113

Nurdalia, I. 2006. Kajian dan Analisis Peluang Penerapan Produksi Bersih Pada usaha Kecil Batik Cap (Studi kasus pada tiga usaha industri kecil batik cap di Pekalongan). Tesis. Program Magister IImu Lingkungan, Universitas Diponegoro: Semarang

Rusnani dan Andini. 2014. Strategi Pemasaran Batik Madura Dalam Menghadapi Pemasaran

Global. Jurnal "PERFORMANCE" Bisnis \& Akuntansi, Vol. 2 September 2014, 14-25

Sulistiono, A dan Mulyana, M. 2010. Strategi Pengembangan Pemasaran Ukm Pengrajin Sepatu Sandal. Hasil Penelitian Peneliti Muda. STIE Kesatuan Bogor

Syamsudin. 2013. Batik dan Pelestariannya. Yogyakarta: Widyaiswara PPPPTK Seni dan Budaya 